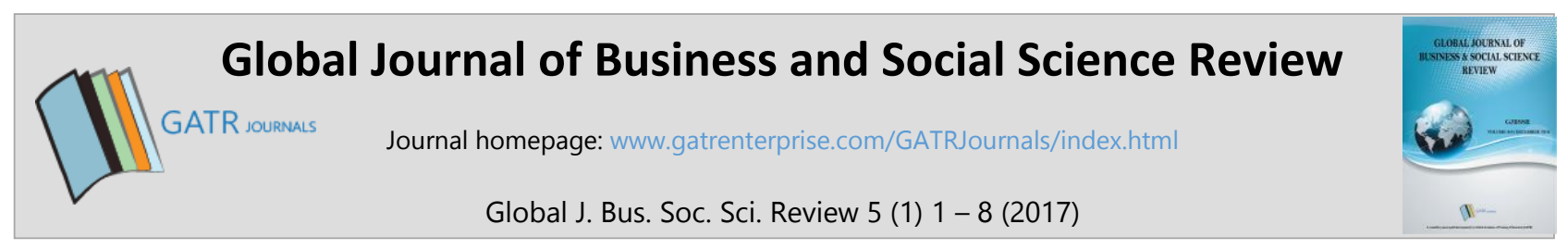

\title{
The Trend of Academic Achievement among Malaysian Boys and Girls: Where are the Boys?
}

\author{
Nor Aniza Ahmad ${ }^{1 *}$, Siti Aishah Hassan ${ }^{2}$, Abdul Razak Ahmad ${ }^{3}$, Chua Lay Nee ${ }^{4}$ and Nor Hashim \\ Othman $^{5}$ \\ ${ }^{1,2}$ Faculty of Educational Studies, Universiti Putra Malaysia, 43400 UPM Serdang, Selangor, Malaysia \\ ${ }^{3}$ Faculty of Education, Universiti Kebangsaan Malaysia, 43600 Bangi, Selangor, Malaysia \\ ${ }^{4}$ Raja Melewar Teacher Trainee College, 70400 Jalan Sikamat, Seremban, Negeri Sembilan, Malaysia \\ ${ }^{5}$ SMK Mambau, Jalan Port Dickson, 70300 Seremban, Negeri Sembilan, Malaysia
}

\begin{abstract}
Objective - Gender differences in education remain as one of the global issues that has been widely and comprehensively discussed. This study aims at exploring the pattern of academic achievement of boys and girls in Malaysia.

Methodology/Technique - The study analyzes the data of student achievement in public examination from 2008 until 2014, which were obtained from the Malaysian Examination Board.

Findings - The findings showed that Malaysian girls performed better than Malaysian boys. The findings also showed that there were significant differences in academic achievement between the boys and the girls.

Novelty - This study implicated the need to identify the factors causing the achievement gap across genders. Hence, strategies and interventions can be undertaken to reduce the gap.
\end{abstract}

Type of Paper: Empirical.

Keywords: Academic Achievement; Boy’s Performance; Girl's Performance; Gender Differences.

JEL Classification: I21, I23

\section{Introduction}

Academic achievement across genders, especially at schools and universities, has continuously been studied either in Malaysia or abroad. In 2011, the Trend in International Mathematics and Science Study (TIMSS) showed a significant difference between genders of grade 8 students when considering the mean score amongst the students in a science subject. The mean score for girls who participated in TIMSS 2011 is higher than that of the boys (Martin et al., 2012; Mullis et al., 2012). In the Programme for International Student Assessment (PISA) 2009, the participants from Georgia, Malaysia, Mauritius, Moldova and Tamil Nadu India showed no

* Paper Info: Revised: September, 2016

Accepted: January, 2017

* Corresponding author:

E-mail: nor.aniza@upm.edu.my

Affiliation: Faculty of Educational Studies, Universiti Putra Malaysia, Malaysia 
significant difference between genders in mathematics, but there was a significant difference in science subjects, the girls performance exceeding that of the boys (ACER, 2011). These findings are similar to Martin et al., (2008), OECD $(2007,2010)$ and EARGED (2007b, 2009) whom reported that girls achieve better than boys in science subjects. However, several studies, in examining academic achievement differences between genders, have addressed the capability of boys to outperform girls in examination (e.g. Hyde et al., 2008). According to Spencer et al., (1999), boys are able to outperform girls in examination due to the high expectation of boys' ability to surpass girls. This situation has added pressure to girls which may later lead to lower achievement in examination as compared to boys. Therefore, these contradictions have showed that both boys and girls are capable of achieving outstanding marks in examination. Nevertheless, the achievement gap between boys and girls is still being reported in studies that have been conducted involving school children around the world; which has called for current research to examine the trend of academic achievement between boys and girls in order to have an insight of this phenomenon in Malaysia.

Mohd Jelas et al., (2013) stated that there are significant differences in academic achievement between genders in Malaysia, and the gap has been widened for five consecutive years from 2006 until 2011. Further findings in Ahmad et al. (2011) show that the gap in academic achievement between genders is not only wide at all levels of public examinations, but has also caused an enrolment imbalance in Malaysian universities. The girls perform better in academics compared to boys in almost all subjects, both in primary and secondary education; the gap having started in primary school and continued into secondary school. Subsequently, it became noticeable at the university level in which $70 \%$ of the cohorts are girls. Thus, this issue needs to be addressed to avoid dropouts among boys, especially at an early age due to lower academic achievement and truancy.

The purpose of this research is to identify the trend of academic achievement in Malaysian public examinations (UPSR, PMR and SPM) based on gender.

Research question are as follows:

i. What is the trend of academic achievement in UPSR based on gender?

ii. What is the trend of academic achievement in PMR based on gender?

iii. What is the trend of academic achievement in SPM based on gender?

\section{Methodology}

The study analyzed the data of student achievement in public examination from 2008 until 2014, which was obtained from the Malaysian Examination Board. Ujian Penilaian Sekolah Rendah (UPSR) is a public examination for primary school students, taken at age 12. Whereas, Peperiksaan Menengah Rendah ('PMR') and Sijil Peperiksaan Malaysia ('SPM') are public examinations for secondary school students taken at age 15 and 17 , respectively. The data was compared between boys and girls for each type of public examination.

\section{Findings}

The findings of this study focused only on academic achievement of our main subjects; Malay language, English language, mathematics and science. 


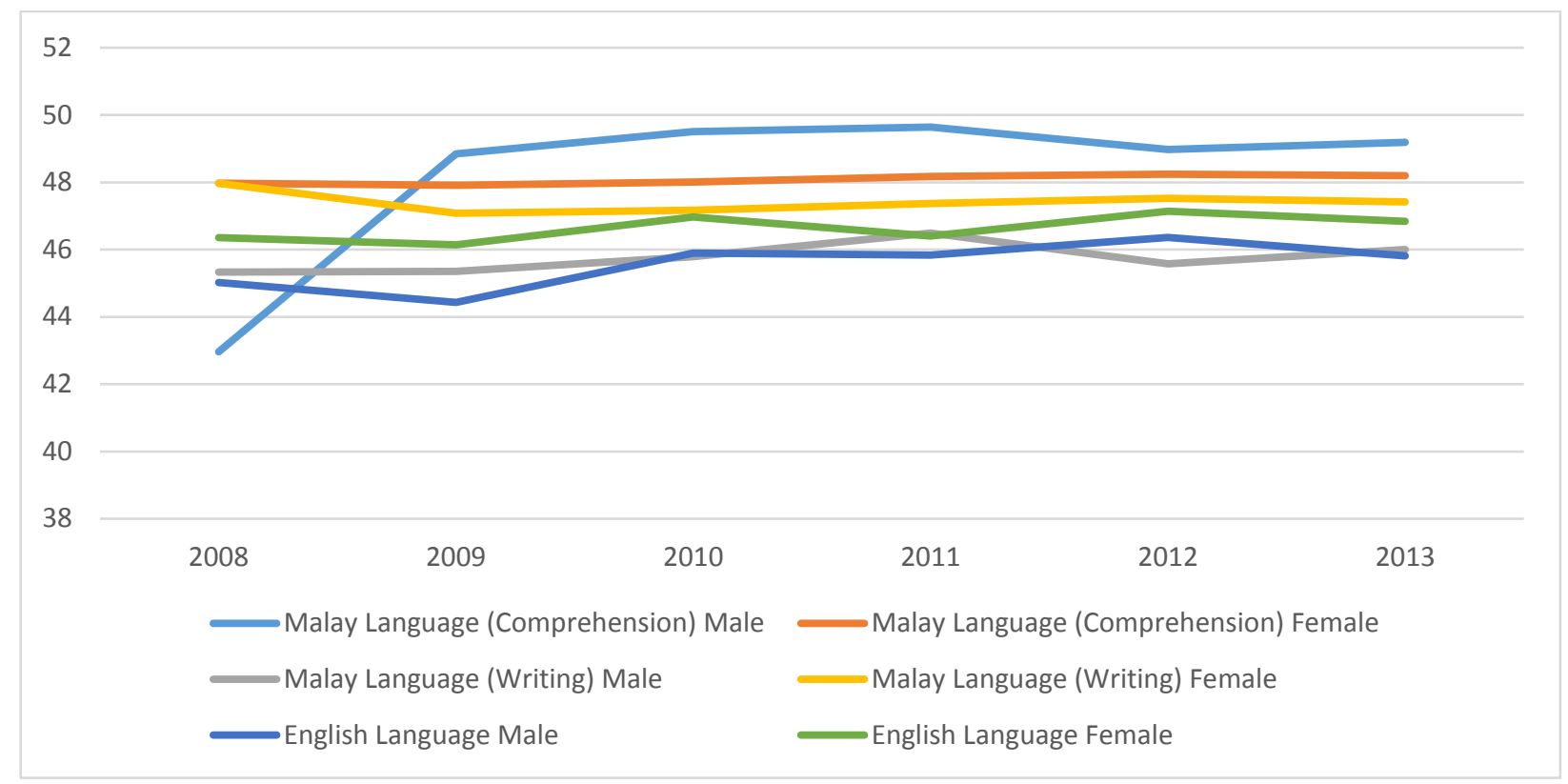

Figure 1. Percentage of Achievement in Malay Language (Comprehension), Malay Language (Writing) and English Language based on Gender for UPSR (2008-2013)

Source: From Malaysian Examinations Syndicate

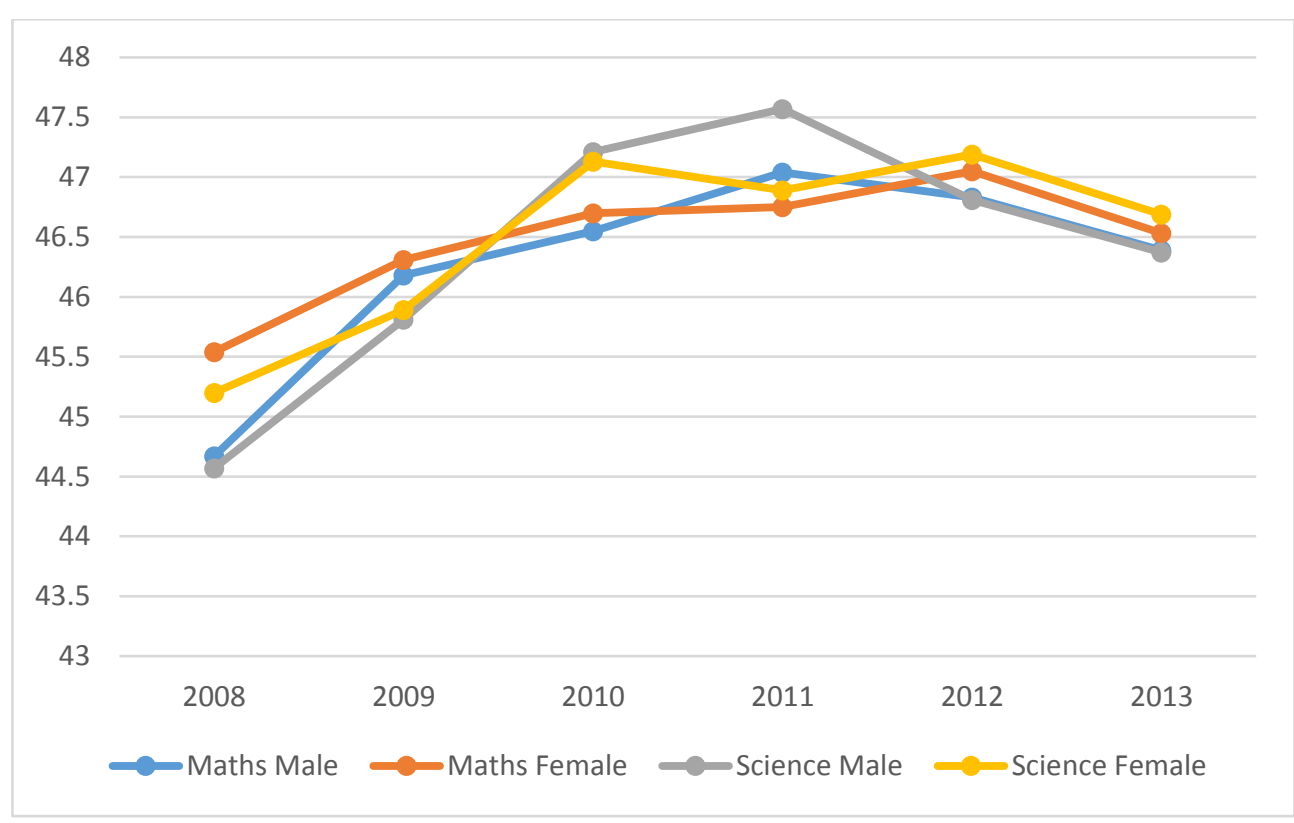

Figure 2. Percentage of Achievement in Mathematics and Science based on Gender For UPSR (2008-2013)

Source: From Malaysian Examinations Syndicate

Figure 1 and Figure 2 show the percentages of student achievement in Malay language, English language, maths and science in UPSR based on gender. For Malay language (Comprehension), the boys showed higher achievement than girls from 2009 until 2013. This finding is contrary to the trend noted from 1996 to 2007 which showed that girls performed better than boys in this subject (Ahmad et al., 2010b). This notable change of trend may be due to gender bias in the exam paper and the implementation of higher order thinking skills (HOTS) teaching and learning modules. For Malay language (Writing) and English, the girls were still showing 
higher achievement than boys from 2008 to 2013. For mathematics and science, the girls also showed higher achievement compared to the boys, except in 2011 where the boys exceeded the girls in mathematics.

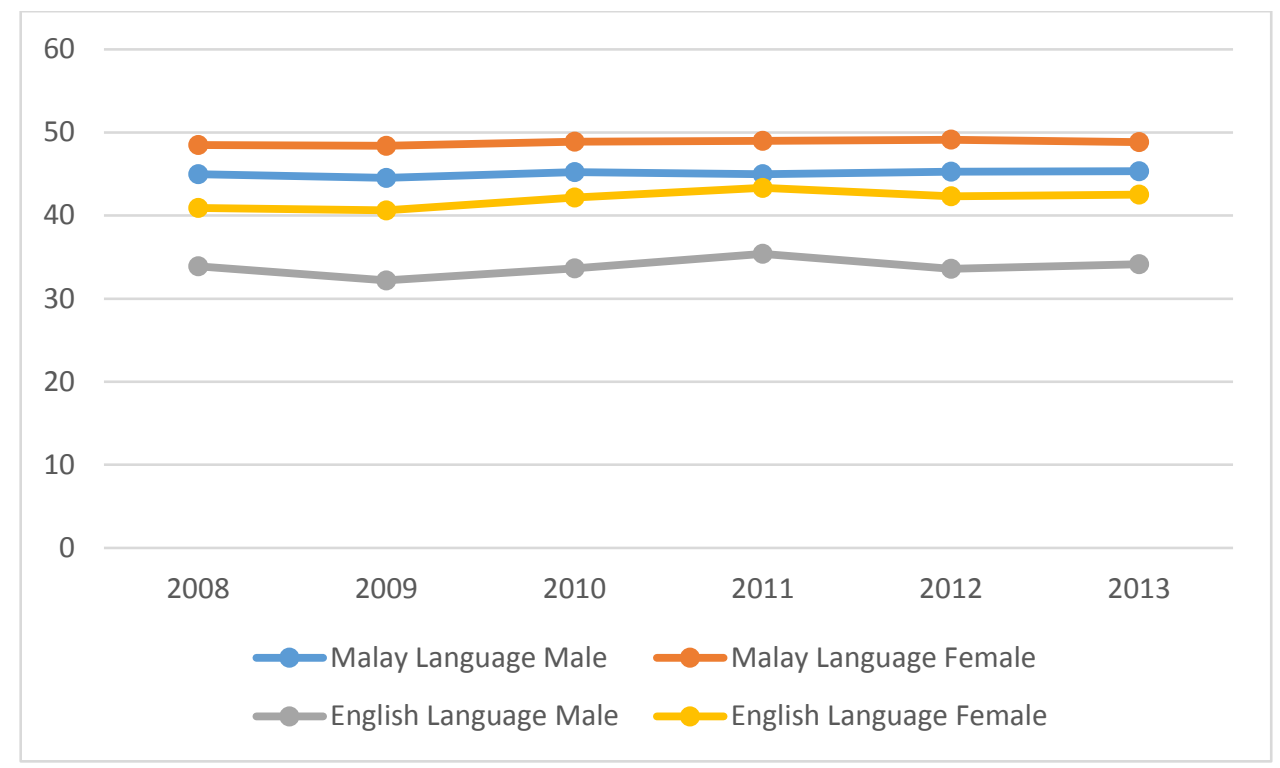

Figure 3. Percentage of Achievement in Malay Language and English Language based on Gender for PMR(2008-2013) Source: From Malaysian Examinations Syndicate

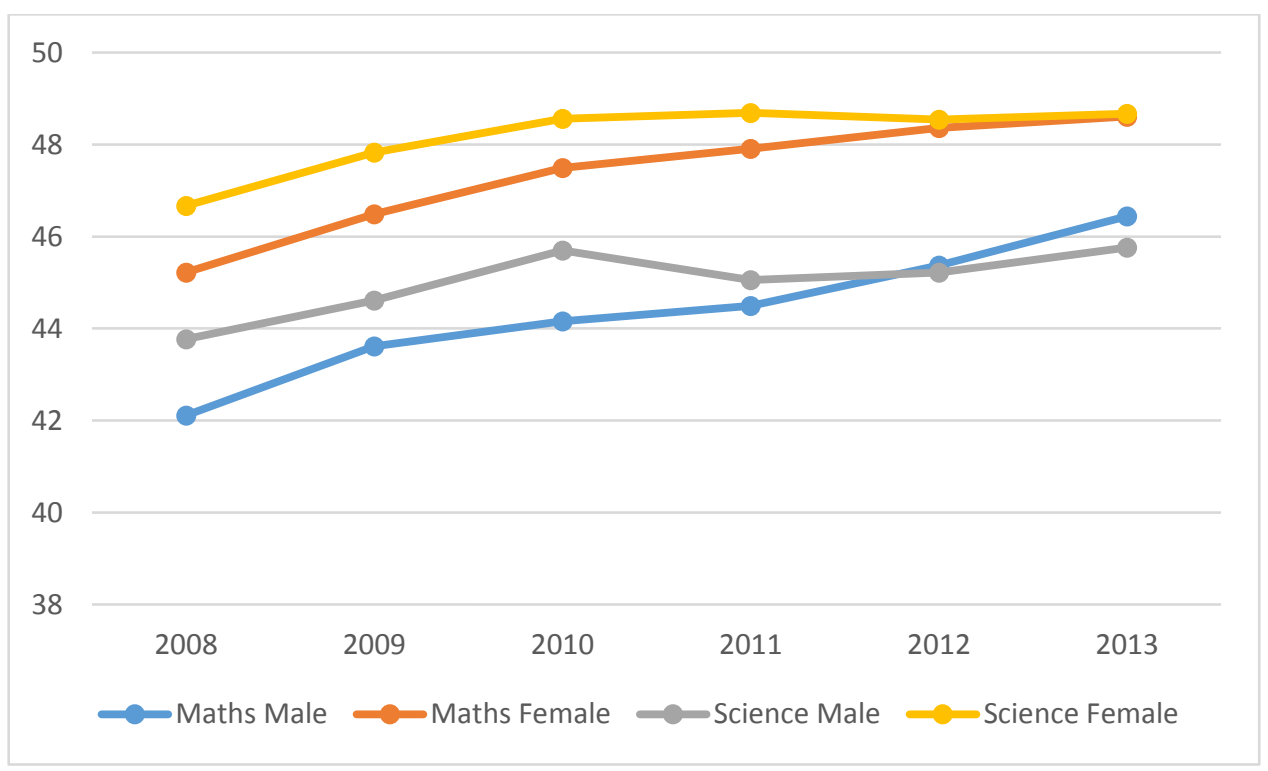

Figure 4. Percentage of Achievement in Mathematics and Science based on Gender For PMR (2008-2013)

Source: From Malaysian Examinations Syndicate

Figure 3 and Figure 4 show the percentages of student performance in Malay language, English language, mathematics and science in PMR based on gender. It was noted that from 2008 to 2013 the achievement of the girls was better than the boys in all subjects. 


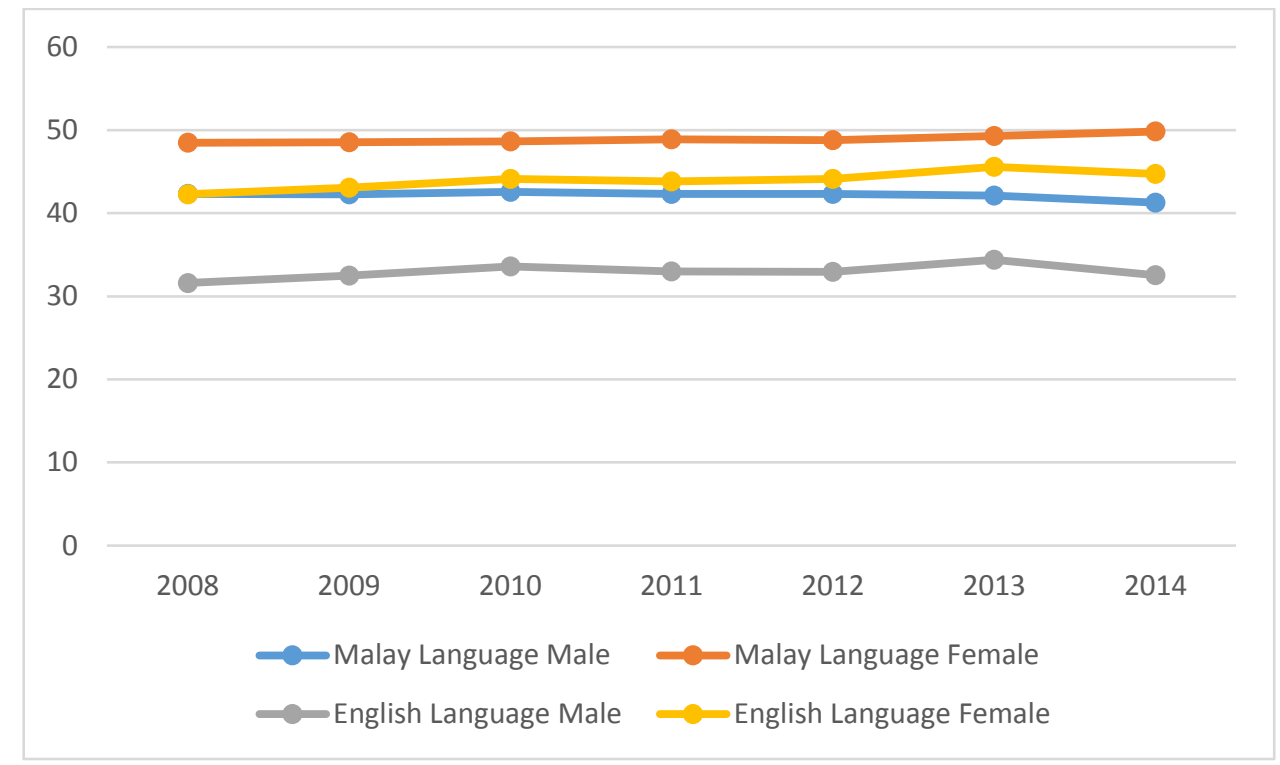

Figure 5. Percentage of Achievement in Malay Language and English Language based on Gender for SPM (2008-2014) Source: From Malaysian Examinations Syndicate

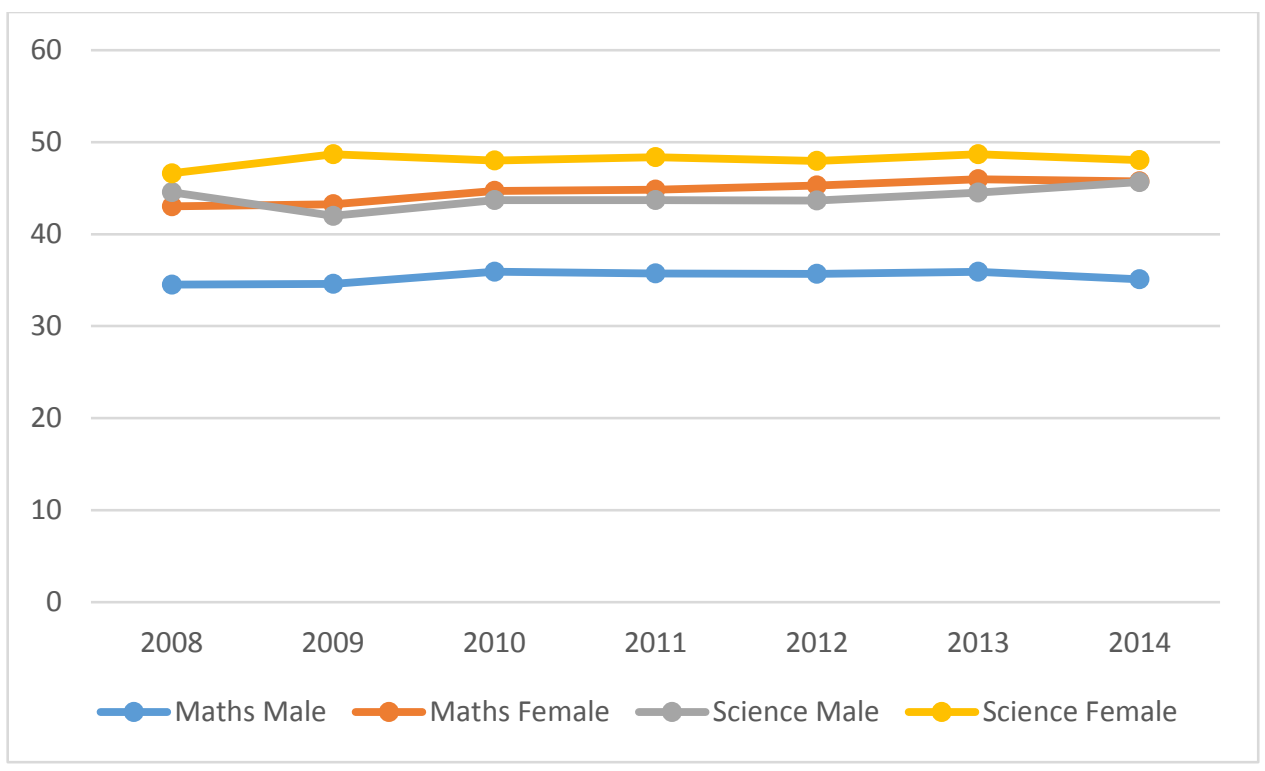

Figure 6. Percentage of Achievement in Mathematics and Science based on Gender For SPM (2008-2014)

Source: From Malaysian Examinations Syndicate

Figure 5 and Figure 6 show the percentages of student performance in Malay language, English language, mathematics and science in SPM based on gender. From 2008 to 2014, the girls showed higher achievement than boys in all subjects.

\section{Discussion and Conclusion}

In primary school years, the difference in academic accomplishment between boys and girls is very marginal. For Malay language (Comprehension), mathematics and science, the boys occasionally achieve higher than the girls in certain years. However, the achievement gap becomes noticeable during the secondary 
school years. The results of both secondary school examinations (PMR and SPM) showed that the girls achieved higher in Malay language, English language, mathematics and science compared to the boys. These findings are similar to other studies which show that girls perform better than boys in academic achievement (Ahmad et al., 2010a; Ahmad et al., 2010b; Al-Mutairi, 2011; Ryabov, 2012; Amro et al., 2015). In Brunei, girls have always shown higher achievement than boys and this eventually lead to higher female enrolment at the university level, whilst the boys experienced a decreasing trend of achievement in a three year period (Ahmad, 2000; MOE, 2005). Studies conducted in Asian countries such as Thailand, Brunei and Malaysia show that girls have better academic achievement compared to boys (Ahmad, 2015; Chung et al., 2001).

Furthermore, some previous studies showed no significant achievement difference between boys and girls in science (Afuwape, 2011; Oludipe, 2012). Habibollah et al., (2009) also reported that there is no significant difference between gender and cumulative grade point average (CGPA) among 153 Iranian students at universities in Malaysia. These mixed findings may be affected by personal variables such as students cognitive ability, motivation and efforts (Olukemi, 1998), and pedagogy variables such as teaching strategy and teacher stereotypes (Oludipe, 2012). In addition, Offor (2007) has also identified a few factors that may cause differences between achievements of the genders such as education opportunities, early marriage, lack of females with a role model, low self-concept, teaching methods and stereotypes between teachers and students.

Furthermore, Dhindsa and Shahrizal-Emran (2011) reported that traditional teaching methods correlate with higher achievement among university students. When traditional teaching methods are converted into a constructivist teaching method, the boys achieve higher grades than the girls. Balfakih (2003) also reported that cooperative teaching methods can reduce the differences of academic achievement across gender in chemistry. These findings are similar to Sakiyo (2008), who stated that there is no significant achievement difference between genders when student centred learning is used. On the other hand, Haynes and Hamilton (1998) believed that the achievement gap between boys and girls depends on the evaluation format and the types of questions being used, either multiple choice or constructed-response questions.

As a conclusion, previous studies in this area have significantly contributed to the literature on the trend of academic achievement between boys and girls in Malaysia, which has helped to eliminate the gap in the literature as suggested by Ismail and Awang (2008). With that in mind, this study can be a baseline for further research into how such trends of academic achievement between boys and girls can be reduced or eliminated; by identifying factors that contribute towards the achievement gap or by producing an intervention that can help to eliminate the gap. In addition, this research will also help to provide information to equip the worldwide trend of academic achievement between boys and girls. From the research that has been conducted, it can also be said that each student poses different abilities, learning styles and learning strategies that can affect his or her achievement. Thus, teachers or educators need to know how to bring out their students ability to the maximum level without any gender bias. Teachers not only have to recognize and respect the differences of their individual students (Dunn et al., 2001; Gurian et al., 2009), but they also have to perceive the students' unique strengths instead of their weaknesses (Sternberg, 1997). As for parents, they should actively participate in their childs' learning, either at school or at home, in order to make their child feels more secure, like they have someone to lean on. Parent involvement has been proven to help students obtain higher academic achievements (Jeynes, 2007; Toldson, 2011; Plunkett et al., 2008; Kordi \& Baharudin, 2010). In other words, the positive values from parent involvement can motivate the students to put in more efforts and perform better in school.

\section{Acknowledgements}

Highest gratitude to the Ministry of Education Malaysia for its financial support of this Fundamental Research Grant Scheme (FRGS 05-02-14-1535FR). 


\section{References}

ACER (Australian Council for Educational Research). (2011, December 16). ACER releases results of PISA 2009+ participant economies. Retrieved on April, 212016 from https://www.acer.edu.au/about-us/media/article/acerreleases-results-of-pisa-2009-participant-economies.

Afuwape, M. O. (2011). Students' self-concept and their achievement in basic science. International Multidisciplinary Journal. Ethiopia. 5(4), 191-200.

Ahmad, N. A (2015). Boy's and Girl's Learnt Differently: Language Learning Strategies and Academic Achievement in Single Sex and Co-Ed Schooling $8^{\text {th }}$ International Conference of Education, Research and Innovation (ICERI) 2015, 16-18 ${ }^{\text {th }}$ November: Seville, Spain.

Ahmad, N. A., Mohd Jelas, Z. \& Mohd Ali, M. (2011). The Relationship of Learning Styles and Learning Strategies with Academic Achievement between Gender and Type of School. International Journal on Learning. 17(10): 265278.

Ahmad, N. A., Mohd Jelas, Z. \& Mohd Ali, M. (2010a). Understanding Students Performance based on Gender and Type of School using SEM. Procedia Social \& Behavioral Science 7, 425-429.

Nor Aniza Ahmad, Zalizan Mohd Jelas \& Manisah Mohd Ali. (2010b). Jurang Akademik Mengikut Gender dan Jenis Sekolah. Journal of Applied Research in Education 14 (2), 217-227.

Ahmad (2000). Opening Address. In Wong, K. Y., Tairab, H. H. and Clements, M. A. Proceedings of the fifth annual conference of the department of the science and mathematics education. pp. 5-7.Universiti Brunei Darussalam, Brunei: ICT.

Al-Mutairi, A. (2011). Factors affecting business students' performance in Arab Open University: The case of Kuwait. International Journal of Business and Management. 6(5), 146-156.

Amro, H. J., Mundy, M. \& Kupczynski, L. (2015). The effects of age and gender on student achievement in face-to-face and online college algebra classes. Research in Higher Education Journal. 27, 1-22.

Balfakih, N.M.A. (2003) . The effectiveness of student team-achievement division (STAD) for teaching high school chemistry in the United Arab Emirates. International Journal of Science Education, 25(5), 605-624.

Chung, G., Riah, H., \& Dhindsa, H. S. (2001). Effects of gender on lower secondary students' attitudes towards, and achievement in, science. Studies in Education. 6, 40-46.

Dhindsa, H. S \& Sharizal-Emran (2011). Using interactive whiteboard technology-rich constructivist learning environment to minimize gender differences in chemistry achievement. International Journal of Environmental and Science Education. 6(4), 393-414.

Dunn, R., Griggs, S.A., Olson, J., Beasley, M. \& Gorman, B.S. (2001). A Meta-analytic validation of the Dunn and Dunn Model of learning-style preferences. The Journal of Educational Research. 88(6), 353-362.

Eğitimi Araştırma ve Geliştirme Dairesi (EARGED). (2007b). ÖBBS 2005: İlköğretim ögrrencilerinin başarllarının belirlenmesi: Fen bilgisi raporu. Ankara: Yazar.

Eğitimi Araştırma ve Geliştirme Dairesi (EARGED). (2009). ÖBBS 2008: İlköğretim öğrencilerinin başarılarının belirlenmesi: Fen ve teknoloji raporu. Ankara: Yazar.

Gurian, M., Stevens, K. \& Daniels, P. (2009). Successful single-sex classrooms: A practical guide to teaching boys and girls separately. San Francisco: Jossey Bass.

Habibollah., N., Rohani., A., Tengku A. H., Jamaluddin, S. V., Mallan, K. (2009). Gender Differences in Creative Perceptions of Undergraduate Students. Journal of Applied Sciences. 9(1), 167-172.

Haynes, N.M., Comer, J.P., \& Hamilton-lee, M. (1988). Gender and achievement status differences on learning factors among blank high school students. Journal of educational Research. 81(4), 233-237.

Hyde, J., Lindberg, S., Linn, M., Ellis, A., \& Williams, C. (2008, July 25). Gender similarities characterize math performance. Education Forum, pp. 494-495.

Ismail, N., \& Awang, H. (2008). Differentials in mathematics achievement among eighth-grade students in Malaysia. International Journal of Science and Mathematics Education. 6(3), 559-571.

Jeynes, W. H. (2007). The relationship between parental involvement and urban secondary school student academic achievement: A meta-analysis. Urban Education. 42(1), 82-110.

Kordi, A., \& Baharudin, R. (2010). Parenting attitude and style and its effect on children's school achievements. International Journal of Psychological Studies. 2, 217-222.

Martin, M.O., Mullis, I.V.S., Foy, P., \& Stanco, G.M. (2012). TIMSS 2011 international results in science. Chestnut Hill, MA: TIMSS \& PIRLS International Study Centre, Boston College. 
Martin, M. O., Mullis, I. V. S., Foy, P., Olson, J. F., Erberger, E., Preuschoff, C. et al. (2008). TIMSS 2007: International science report. Boston College, MA.: TIMSS \& PIRLS International Study Centre.

MOE (2005). Education statistics 2003, 2004 and 2005. Brunei: Ministry of Education.

Mohd Jelas, Z., Mohd. Salleh, A., Azman, N., Hamzah, R., Jani, R. Hamzah, H., Abd Hamid, Z. \& Mahmud, M. I. (2013). Analisis Gender Dalam Pendidikan: Laporan Akhir Kajian KPT.R.620-1/1/3. 32(17).

Mullis, I.V.S., Martin, M.O., Foy, P., \& Arora, A. (2012). TIMSS 2011 international results in mathematics. Chestnut Hill, MA: TIMSS \& PIRLS International Study Center, Boston College.

Offor, E. I. (2007). Gender Stereotyping in some Popular Primary Science Textbooks used in Primary Schools in Imo State: Journal of Women in Academies. 4(1), 232-240.

Oludipe, D. I (2012). Gender Difference in Nigerian Junior Secondary Students' Academic Achievement in Basic Science. Journal of Educational and Social Research. 2(1), 93- 99.

Olukemi, O. B. (1998). Ensuring Active Participation of Girl in Science and Technology, Plans Towards the year 200. Journal of Women in colleges of Education. 2(1), 117-119.

Organisation for Economic Co-operation and Development (OECD). (2007). PISA 2006 science competencies for tomorrow's world: Executive summary.

Organisation for Economic Co-operation and Development (OECD). (2010). PISA 2009 results: Executive summary.

Plunkett, S. W., Henry, C. S., Houltberg, B. J., Sands, T., \& Abarca-Mortensen, S. (2008). Academic support by significant others and educational resilience in Mexican origin ninth grade students from intact families. Journal of Early Adolescence. 28, 333-355.

Ryabov, I. (2012). The effect of time online on grades in online sociology courses. Journal of Online Learning and Teaching.8(1), 13-23.

Sakiyo J. (2008). Effectiveness of Science technology Society Teaching Method on Students' Acquisition of Science Process Skills in Yola Metropolis, Adamawa State. Journal of Technology and Educational Research. 1(2), 89100.

Spencer, S. J., Steele, C. M., \& Quinn, D. M. (1999). Stereotype threat and women's math performance. Journal of experimental social psychology, 35(1), 4-28.

Sternberg, R.J. (1997). Thinking styles. New York: Cambridge University Press.

Toldson, A. (2011). Breaking Barriers 2: Plotting the Path to Academic Success for School-age African-American Males. Congressional Black Caucus Foundation. 